\title{
New psychrophilic and psychrotolerant Bacillus marinus strains from tropical and polar deep-sea sediments and emended description of the species
}

\author{
Hans-Jürgen Rüger, ${ }^{1}$ Dagmar Fritze ${ }^{2}$ and Cathrin Spröer ${ }^{2}$ \\ Author for correspondence: Dagmar Fritze. Tel: +49 5312616 254. Fax: +49 5312616418. \\ e-mail: dfr@dsmz.de
}

1 Alfred-Wegener-Institut für Polar- und Meeresforschung, Am Handelshafen 12, D-27570 Bremerhaven, Germany

2 Deutsche Sammlung von Mikroorganismen und Zellkulturen $\mathrm{GmbH}$, Mascheroder Weg $1 \mathrm{~b}$, D-38124 Braunschweig, Germany

\begin{abstract}
In contrast to the current view that psychrophily combined with an absolute requirement for $\mathrm{NaCl}$ is connected with the Gram-negative cell wall type, psychrophilic and psychrotolerant, NaCl-requiring, Gram-positive bacteria have been isolated from tropical Atlantic, Arctic and Antarctic deep-sea sediments. Some of the isolates are even extremely psychrophilic, having maximum growth temperatures of $4^{\circ} \mathrm{C}$. On the basis of phenotypic characteristics, DNA base analyses, DNA-DNA hybridizations and partial and complete 16S rRNA gene sequence analyses, the strains from the three distinct geographical regions have been allocated to the obligately marine species Bacillus marinus. The distribution and origin of $B$. marinus are discussed and an emended description of the species is presented.
\end{abstract}

Keywords: Bacillus marinus, $\mathrm{NaCl}$ requirement, psychrophilic, polar regions, tropical deep sea

\section{INTRODUCTION}

Members of the genus Bacillus are ubiquitous in terrestrial and freshwater habitats and are also widely distributed in the world oceans (ZoBell \& Upham, 1944; ZoBell, 1946; Denis et al., 1975; Brisou et al., 1978; Bonde, 1981; Rüger, 1989). Bacilli from seawater samples and marine bottom deposits are moderately halotolerant. They are able to propagate and to metabolize under marine conditions, but the vast majority are not dependent on seawater media for growth and are therefore supposed to be of terrestrial origin.

So far, only a few seawater medium-requiring Bacillus strains have been isolated from marine sources (Brisou \& Denis, 1969; Fahmy, 1978; Boeyé \& Aerts, 1976; Rüger \& Koploy, 1980). Bacillus marinus, originally described as Bacillus globisporus subsp. marinus by Rüger \& Richter (1979) and later elevated to

Abbreviations: DAP, diaminopimelic acid; FWB, freshwater broth; MOF, marine oxidation/fermentation; SWA, seawater agar; SWB, seawater broth.

The EMBL accession number of the 16S rDNA gene sequence of Bacillus marinus DSM $1297^{\top}$ is AJ237708. species rank (Rüger, 1983), proved to be dependent on sodium and potassium ions for growth and is therefore regarded as a true marine species (Rüger \& Hentzschel, 1980).

Many of the marine and terrestrial environments inhabited by members of the genus Bacillus are permanently, seasonally or temporarily cold, with temperatures near $0{ }^{\circ} \mathrm{C}$ or below. It is not surprising, therefore, that numerous Bacillus strains capable of growing at low temperatures could be isolated from many different habitats (Larkin \& Stokes, 1966; Laine, 1970; Abd El-Rahman, 1988). Marshall \& Ohye (1966) described the cold-adapted Bacillus macquariensis from soils of the Antarctic Macquarie Island and Larkin \& Stokes (1967) reported the taxonomy of four new Bacillus species able to grow at $0{ }^{\circ} \mathrm{C}$ or below, namely Bacillus psychrosaccharolyticus, Bacillus insolitus, Bacillus globisporus and Bacillus psychrophilus.

Until now, there has been no binding definition of the term psychrophilic. The most accepted definition is that given by Morita (1975), requiring growth at $0{ }^{\circ} \mathrm{C}$ or at subzero temperatures, optimum growth temperatures of $15^{\circ} \mathrm{C}$ or lower and maximum growth temperatures of below $20^{\circ} \mathrm{C}$. Cold-adapted bacteria with maximum growth temperatures higher than $20^{\circ} \mathrm{C}$ 
are regarded as 'psychrotrophic' (Baross \& Morita, 1978). In accordance with these definitions, all the cold-adapted bacilli mentioned above are therefore 'psychrotrophic', including those strains that were originally characterized as psychrophilic.

Instead of 'psychrotrophic', which means 'cold-eating', the term psychrotolerant seems to be more logical for organisms normally growing at temperatures above $20{ }^{\circ} \mathrm{C}$, but also being able to grow at near $0{ }^{\circ} \mathrm{C}$ or below (Russell, 1993; Nedwell \& Rutter, 1994). Therefore, the term psychrotolerant is preferred in this paper.

In contrast to the current view, that strict psychrophily plus an absolute requirement for $\mathrm{NaCl}$ is connected with the Gram-negative cell wall type, Rüger \& Tan (1992) reported the isolation of psychrophilic, seawater-requiring, Gram-positive bacteria from the permanently cold deep-sea floor of the eastern tropical Atlantic. During two subsequent expeditions in 1987 and 1990, aerobic spore-forming bacteria with the same phenotypic characteristics as the tropical deepsea strains have been isolated from Arctic and Antarctic bottom sediments. On the basis of DNA base analyses, DNA-DNA hybridizations and 16S rRNA gene sequencing, the strains from these three distinct geographical regions have been allocated to $B$. marinus. The distribution and origin of this species are discussed and an emended description of B. marinus is presented, incorporating the phenotypic characteristics of the new isolates.

\section{METHODS}

Isolation of strains. The bacteria listed in Table 1 were isolated from sediment samples during the expedition GEOTROPEX '83 with the German research vessel Meteor in the eastern tropical Atlantic in 1983 and during two expeditions with the German research vessel Polarstern in 1987 and 1990 in the Arctic and Antarctic seas, respectively. The geographical positions of sampling sites and the corrected depths were taken from Sarnthein et al. (1983), Tan \& Rüger (1991) and Tan et al. (1999).

Sediment sample processing and isolation of strains were done as described previously (Rüger \& Tan, 1992). All solutions and agar media were pre-chilled to $4{ }^{\circ} \mathrm{C}$ and held at this temperature on a cold tray during the whole inoculation procedure. Seawater agar (SWA) according to ZoBell (1946) was used as isolation medium, but was modified and consisted of $1.5 \mathrm{~g}$ Bacto Peptone, $0.3 \mathrm{~g}$ yeast extract, $0.01 \mathrm{~g}$ $\mathrm{FePO}_{4} \cdot 4 \mathrm{H}_{2} \mathrm{O}, 10 \cdot 0 \mathrm{~g}$ Agar no. 1 (Oxoid), $750 \mathrm{ml}$ seawater and $250 \mathrm{ml}$ distilled water; $\mathrm{pH} \mathrm{7.6.} \mathrm{The} \mathrm{incubation}$ temperatures were 2 and $20^{\circ} \mathrm{C}$ for the tropical strains and $4{ }^{\circ} \mathrm{C}$ for the polar strains. For isolation of Bacillus strains from dormant spores (strains A02712, A02720, A02800, A02819, A02735, A02736 and A02738), dilutions of sediment subsamples were heated for $10 \mathrm{~min}$ at 80 and $90^{\circ} \mathrm{C}$ and spread onto spore germination medium II (Rüger, 1975).

Spore formation. The ability to form endospores was determined in the following test media: SWA, SWA with the addition of $15 \cdot 38 \mathrm{mg} \mathrm{MnSO}_{4} . \mathrm{H}_{2} \mathrm{O} \mathrm{1^{-1 }}$ and $15.38 \mathrm{mg}$ $\mathrm{CaCl}_{2} \cdot 2 \mathrm{H}_{2} \mathrm{Ol}^{-1}$ and in seawater broth (SWB) supplemented with $1.8 \mathrm{mM}$ (final concentration) decoyinine, psicofuranine or psicofuranine tetraacetate (Zain-ul-Abedin et al., 1983; Rüger \& Tan, 1992). Evaluation of spore formation was done microscopically after 4 and 8 weeks incubation at $4{ }^{\circ} \mathrm{C}$. The composition of SWB is given below.

Physiological characterization of strains. The tests for identification of strains were performed in seawater media as described previously (Rüger \& Richter, 1979; Rüger \& Höfle, 1992). Test temperatures were $4{ }^{\circ} \mathrm{C}$; only the $20^{\circ} \mathrm{C}$ isolates A03029, A03051 and A03126 were tested at $20^{\circ} \mathrm{C}$. Fermentation of carbohydrates was determined with the Minitek identification system after 2, 4, 7 and $14 \mathrm{~d}$ incubation (Rüger, 1981). Fermentation of glucose was additionally tested in the marine oxidation/fermentation (MOF) medium developed by Leifson (1963).

Susceptibility to antibiotics was determined with Oxoid disks loaded with the various amounts of antibiotics given, placed on agar plates prepared with $10 \mathrm{ml}$ SWA.

Utilization of organic compounds as sole sources of carbon and energy was studied in standard microtitre plates by means of a multipoint inoculator (Rüger, 1988). In order to detect possible cross-contamination, three neighbouring wells were taken for each strain. Turbidity was used as an indicator for substrate utilization and was measured with a microtitre plate photometer at $405 \mathrm{~nm}$ after 2, 4, 6 and 8 weeks incubation. An increase in turbidity of more than $0 \cdot 1$ OD unit was considered a positive result.

The composition of the cell walls, i.e. the presence/absence of diaminopimelic acid (DAP), was evaluated following the method described by Kandler \& Weiss (1986).

Growth characteristics of strains. Optimal and maximal growth temperatures of the tropical isolates were determined at $4,12,18,24,30$ and $37^{\circ} \mathrm{C}$ in SWB, consisting of $5.0 \mathrm{~g}$ Bacto Peptone, $1.0 \mathrm{~g}$ yeast extract, $0.01 \mathrm{~g} \mathrm{FePO}_{4} .4 \mathrm{H}_{2} \mathrm{O}, 750$ $\mathrm{ml}$ seawater and $250 \mathrm{ml}$ distilled water; $\mathrm{pH} 7 \cdot 6$. Growth was measured by monitoring optical density at $650 \mathrm{~nm}$ with a Gilford photometer model 250. For the polar isolates, the microtitre plate method as described above was used with the same seawater medium, but with incubation temperatures of $1,4,8,12,18,24,30$ and $37^{\circ} \mathrm{C}$ for the Arctic strains and $1,4,8,12,16,20,24,30$ and $37^{\circ} \mathrm{C}$ for the Antarctic strains. Turbidity measurements were performed after 3,7 and $14 \mathrm{~d}$ incubation and turbidity increases of $>0 \cdot 1 \mathrm{OD}$ unit were taken as positive results.

The microtitre plate method was also applied to determine the $\mathrm{NaCl}$ requirements of the strains. The basic test medium, supplemented with $1 \mathrm{ml}$ of a vitamin stock solution $1^{-1}$ (Rüger, 1988), has been described previously (Rüger \& Hentzschel, 1980). Growth was tested at the following $\mathrm{NaCl}$ concentrations: $0,25,100,200,300,400,600,800,1000$, $1500,2000,2500$ and $3000 \mathrm{mM}$. Turbidity was measured after $1,3,7,14$ and $21 \mathrm{~d}$ incubation at 4 and $20^{\circ} \mathrm{C}$.

Seawater requirements of the strains were tested by comparing growth in SWB and freshwater broth (FWB), containing the same constituents as SWB but prepared with distilled water.

Interpretation of the test results for growth temperatures and $\mathrm{NaCl}$ requirements. A maximum growth temperature of $24{ }^{\circ} \mathrm{C}$, for instance, means that growth occurred at $24^{\circ} \mathrm{C}$ but not at the next higher temperature tested. Thus, the real maximum is somewhere between 24 and $30{ }^{\circ} \mathrm{C}$. Similarly, a 
Table 1. Strains used in this study

Agar plates for isolation of strains were incubated at $2{ }^{\circ} \mathrm{C}$ (tropical isolates) or $4{ }^{\circ} \mathrm{C}$ (polar isolates). Exceptions were strains A03029, A03051 and A03126, isolated from agar plates incubated at $20^{\circ} \mathrm{C}$. Strains were isolated on the following expeditions: GEOTROPEX '83, 1983 (tropical Atlantic), ARK IV/2, 1987 (Arctic Ocean) and ANT VIII/6, 1990 (Antarctic Ocean).

\begin{tabular}{|c|c|c|c|c|c|}
\hline \multirow[t]{2}{*}{ Strain } & \multicolumn{3}{|c|}{ Sampling site } & \multirow[t]{2}{*}{ Depth (m) } & \multirow{2}{*}{$\begin{array}{l}\text { Sediment } \\
\text { layer }(\mathrm{cm})\end{array}$} \\
\hline & Station & Latitude & Longitude & & \\
\hline \multicolumn{6}{|l|}{ Tropical Atlantic } \\
\hline A02605 (=DSM 12258) & 373 & $09^{\circ} 14 \cdot 3^{\prime} \mathrm{N}$ & $19^{\circ} 37 \cdot 7^{\prime} \mathrm{W}$ & 4694 & $4-6$ \\
\hline $\begin{array}{l}\mathrm{A} 02685 \text { (=DSM 12323), A02712, A02720, A02735, } \\
\text { A02736, A02738 }\end{array}$ & 381 & $05^{\circ} 37 \cdot 0^{\prime} \mathrm{N}$ & $19^{\circ} 58 \cdot 9^{\prime} \mathrm{W}$ & 2811 & $0-2$ \\
\hline $\begin{array}{l}\text { A02761, A02766, A02767 (=DSM 11891), A02788, } \\
\text { A02800 }\end{array}$ & 381 & $05^{\circ} 37 \cdot 0^{\prime} \mathrm{N}$ & $19^{\circ} 58 \cdot 9^{\prime} \mathrm{W}$ & 2811 & $4-6$ \\
\hline A02819 (=DSM 11894) & 383 & $02^{\circ} 59 \cdot 8^{\prime} \mathrm{N}$ & $22^{\circ} 02 \cdot 5^{\prime} \mathrm{W}$ & 4514 & $0-2$ \\
\hline A 02827 & 388 & $16^{\circ} 56 \cdot 2^{\prime} \mathrm{N}$ & $17^{\circ} 55 \cdot 5^{\prime} \mathrm{W}$ & 2766 & $0-2$ \\
\hline A03029 (=DSM 11898) & 371 & $09^{\circ} 55 \cdot 3^{\prime} \mathrm{N}$ & $17^{\circ} 52 \cdot 8^{\prime} \mathrm{W}$ & 1507 & $4-6$ \\
\hline A03051 (=DSM 11899) & 373 & $09^{\circ} 14 \cdot 3^{\prime} \mathrm{N}$ & $19^{\circ} 37 \cdot 7^{\prime} \mathrm{W}$ & 4694 & $4-6$ \\
\hline A03126 (=DSM 12259) & 376 & $09^{\circ} 08 \cdot 2^{\prime} \mathrm{N}$ & $19^{\circ} 01 \cdot 8^{\prime} \mathrm{W}$ & 4802 & $4-6$ \\
\hline \multicolumn{6}{|l|}{ Arctic Ocean } \\
\hline AR3353 (=DSM 12296) & $11 / 223$ & $75^{\circ} 33 \cdot 3^{\prime} \mathrm{N}$ & $08^{\circ} 48 \cdot 8^{\prime} \mathrm{W}$ & 2629 & $0-2$ \\
\hline $\begin{array}{l}\text { AR3393 (=DSM 11895), AR3396 (=DSM 11892), } \\
\text { AR3398 (=DSM 11893) }\end{array}$ & $11 / 235$ & $75^{\circ} 09 \cdot 4^{\prime} \mathrm{N}$ & $12^{\circ} 27 \cdot 6^{\prime} \mathrm{W}$ & 403 & $0-2$ \\
\hline AR3447 & $11 / 248$ & $72^{\circ} 13 \cdot 4^{\prime} \mathrm{N}$ & $16^{\circ} 04 \cdot 3^{\prime} \mathrm{W}$ & 1450 & $0-2$ \\
\hline \multicolumn{6}{|l|}{ Antarctic Ocean } \\
\hline GU4214 (= DSM 12359) & $16 / 516$ & $66^{\circ} 03 \cdot 7^{\prime} \mathrm{S}$ & $33^{\circ} 16 \cdot 6^{\prime} \mathrm{E}$ & 1357 & $0-2$ \\
\hline $\begin{array}{l}\text { GU4223 (=DSM 12356), GU4227, GU4233 (= DSM } \\
\text { 11896), GU4234 (=DSM 11897) }\end{array}$ & $16 / 518$ & $64^{\circ} 57 \cdot 3^{\prime} \mathrm{S}$ & $33^{\circ} 37 \cdot 7^{\prime} \mathrm{E}$ & 2225 & $0-2$ \\
\hline \multicolumn{6}{|l|}{ Reference strain } \\
\hline B. marinus DSM $1297^{\mathrm{T}}\left(=\mathrm{ATCC} 29841^{\mathrm{T}}\right)$ & & & & & \\
\hline
\end{tabular}

maximum $\mathrm{NaCl}$ concentration of $1000 \mathrm{mM}$ means growth at $1000 \mathrm{mM}$ but not at the next higher concentration tested, and a minimum of $100 \mathrm{mM}$ means growth at $100 \mathrm{mM}$ but not at the next lower concentration, of $25 \mathrm{mM}$.

DNA base composition. The $\mathrm{G}+\mathrm{C}$ content of the DNA was determined from the thermal denaturation profile (Marmur \& Doty, 1962), obtained with a Gilford model 250 spectrophotometer equipped with a Gilford model 2527 thermoprogrammer and calculated by using the equation of De Ley (1970). DNA from Escherichia coli K-12 was used as a reference. $\mathrm{G}+\mathrm{C}$ ratios were determined from nine melting curves per strain.

DNA-DNA hybridization. DNA-DNA relatedness was determined from renaturation rates according to the protocol given by Fritze et al. (1990), based on the methods reported by De Ley et al. (1970) and Gillis et al. (1970).

For hybridizations with the type strain of B. marinus, DNA preparation was done according to Cashion et al. (1977). Renaturation rates of these analyses were calculated using the TRANSFER.BAS computer program of Jahnke (1992).

16S rDNA sequence determination and analysis. Genomic DNA extraction, PCR-mediated amplification of 16S rDNA and sequencing of the PCR products were as described by Rainey et al. (1996). The sequence reaction products were electrophoresed using an Applied Biosystems 373A DNA sequencer. The $16 \mathrm{~S}$ rDNA sequences were aligned manually with members of Bacillus rRNA group 2 using the ae 2 editor
(Maidak et al., 1996). Evolutionary distances were calculated by the method of Jukes \& Cantor (1969). Phylogenetic dendrograms were constructed using the treeing algorithm of De Soete (1983).

\section{RESULTS}

\section{Growth temperatures and $\mathrm{NaCl}$ requirements}

From tropical deep-sea sediments, 131 Bacillus strains were isolated from plates incubated at $2{ }^{\circ} \mathrm{C}$ and 147 from plates incubated at $20^{\circ} \mathrm{C}$. In contrast to the latter, the majority of the $2{ }^{\circ} \mathrm{C}$ strains required seawater media for growth, were psychrophilic or psychrotolerant (Table 2) and had almost identical phenotypic characteristics (Rüger \& Tan, 1992). Twenty-one taxonomically and physiologically comparable Bacillus strains were isolated from Arctic sediment samples and 41 from Antarctic sediment samples.

Besides testing the seawater requirements of all 340 isolates by comparing growth in SWB and in $\mathrm{FWB}$, the minimum, optimum and maximum $\mathrm{NaCl}$ concentrations for growth were additionally determined for the 27 strains chosen as representative of all strains. The $\mathrm{NaCl}$ requirements of the strains in relation to their growth temperatures are compiled in Table 2. All 
Table 2. Growth temperatures and $\mathrm{NaCl}$ requirements of $B$. marinus strains

All strains were able to grow at the lowest temperatures tested, namely $1{ }^{\circ} \mathrm{C}$ for the polar isolates, the isolation temperature of $2{ }^{\circ} \mathrm{C}$ for the tropical deep-sea strains and $4{ }^{\circ} \mathrm{C}$ for the three $20^{\circ} \mathrm{C}$ isolates A03029, A03051 and A03126. NG, No growth.

\begin{tabular}{|c|c|c|c|c|c|}
\hline \multirow[t]{2}{*}{ Strain } & \multicolumn{2}{|c|}{ Growth temperature $\left({ }^{\circ} \mathrm{C}\right)$} & \multicolumn{3}{|c|}{$\mathrm{NaCl}$ requirement $(\mathrm{mM})$ at $4^{\circ} \mathrm{C}$} \\
\hline & Optimum & Maximum & Minimum & Optimum & Maximum \\
\hline \multicolumn{6}{|c|}{ Tropical Atlantic } \\
\hline A02605 & $18-24$ & 24 & 0 & $300-400$ & 1000 \\
\hline A02685 & 4 & 12 & 200 & 300 & 400 \\
\hline $\mathrm{A} 02712$ & 4 & 18 & 100 & $300-400$ & 800 \\
\hline A02720 & 4 & 12 & 200 & $200-300$ & 400 \\
\hline A02735 & 12 & 18 & 100 & $200-400$ & 800 \\
\hline A02736 & 12 & 18 & 200 & 400 & 800 \\
\hline A02738 & 12 & 18 & 300 & 300 & 600 \\
\hline A02761 & 4 & 12 & 100 & 400 & 600 \\
\hline A02766 & 12 & 24 & 200 & 300 & 800 \\
\hline A02767 & 4 & 4 & 100 & 200 & 400 \\
\hline A02788 & 12 & 24 & 100 & $300-400$ & 1000 \\
\hline A02800 & 4 & 4 & 100 & 300 & 800 \\
\hline A02819 & $4-12$ & 24 & 100 & $200-300$ & 800 \\
\hline A02827 & 12 & 24 & 25 & $200-300$ & 1000 \\
\hline A03029 & $12-24$ & 24 & 25 & $300-400$ & 1500 \\
\hline A03051 & $12-24$ & 30 & 100 & $300-400$ & 1000 \\
\hline A03126 & $12-24$ & 24 & 100 & 400 & 1000 \\
\hline \multicolumn{6}{|c|}{ Arctic Ocean } \\
\hline AR3353 & 4 & 12 & 200 & $300-400$ & 1000 \\
\hline AR3393 & 8 & 12 & 100 & $300-600$ & 1000 \\
\hline AR3396 & 4 & 12 & 100 & 300 & 800 \\
\hline AR3398 & $1-4$ & 4 & 200 & $300-400$ & 1000 \\
\hline AR3447 & $8-12$ & 12 & NG & NG & NG \\
\hline \multicolumn{6}{|c|}{ Antarctic Ocean } \\
\hline GU4214 & $8-12$ & 16 & 100 & $300-400$ & 1000 \\
\hline GU4223 & 8 & 16 & 100 & $200-300$ & 600 \\
\hline GU4227 & 8 & 12 & 200 & $300-400$ & 800 \\
\hline GU4233 & 8 & 16 & 100 & $200-400$ & 800 \\
\hline GU4234 & $8-12$ & 20 & 100 & $200-400$ & 1000 \\
\hline
\end{tabular}

strains except A02605 required at least 25 or $100 \mathrm{mM}$ $\mathrm{NaCl}$ for growth. The optimum concentrations of 200-400 $\mathrm{mM}$ correspond to $1 \cdot 2-2 \cdot 4 \% \mathrm{NaCl}$, approximately the natural $\mathrm{NaCl}$ concentration of seawater. In comparison with SWB, the synthetic medium used in the $\mathrm{NaCl}$ requirement tests seemed to be suboptimal. Strain A02819, for instance, still showed slight growth at $24{ }^{\circ} \mathrm{C}$ in SWB, but failed to grow at $20^{\circ} \mathrm{C}$ in the salt test (result not presented in Table 2), and the psychrophilic strain AR3447 did not grow in the salt test even at $4{ }^{\circ} \mathrm{C}$.

\section{Morphological and physiological characterization}

Cell morphology and colony form details are given below in the emended description of B. marinus. Not all strains were motile; only 12 of the 27 strains formed endospores and in eight other strains, spore formation was questionable (Table 3). Additional sporulation could not be induced by the use of media containing decoyinine, psicofuranine or psicofuranine tetraacetate.

Biochemical and nutritional characters for which all strains were positive or negative are also given in the emended species description. Characteristics for which there were strain differences are listed in Table 3 . Fermentation of carbohydrates was tested with the Minitek system. For glucose, the MOF medium of Leifson (1963) was additionally used. All strains produced acid from glucose in the MOF medium, but only the Arctic and Antarctic isolates gave positive results with the Minitek system. There is no reasonable explanation for the differences in carbohydrate fermentation results obtained with these two methods, since the Minitek system proved to be useful for the differentiation of marine bacteria in a comparative study (Rüger, 1981). The polar strains seem to be more active than the tropical isolates, as can be seen from the 
Table 3. Phenotypic characteristics that differ among B. marinus strains

Strains are identified as: Ref, DSM $1297^{\mathrm{T}} ; 1, \mathrm{~A} 02605 ; 2, \mathrm{~A} 02685 ; 3, \mathrm{~A} 02712 ; 4, \mathrm{~A} 02720 ; 5, \mathrm{~A} 02735 ; 6, \mathrm{~A} 02736 ; 7, \mathrm{~A} 02738 ; 8$, A02761; 9, A02766; 10, A02767; 11, A02788; 12, A02800; 13, A02819; 14, A02827; 15, A03029; 16, A03051; 17, A03126; 18, AR3353; 19, AR3393; 20, AR3396; 21, AR3398; 22, AR3447; 23, GU4214; 24, GU4223; 25, GU4227; 26, GU4233; and 27, GU4234. Characteristics are scored as: +, positive; (+), weakly positive; $(-)$, very weak positive reaction; -, negative; ?, formation of endospores questionable; NT, not tested. Characteristics of strain DSM $1297^{\mathrm{T}}$, the type strain of B. marinus, were taken from Rüger \& Richter (1979) and Rüger (1983).

\begin{tabular}{|c|c|c|c|c|c|c|c|c|c|c|c|c|c|c|c|c|c|c|c|c|c|c|c|c|c|c|c|c|}
\hline \multirow[t]{3}{*}{ Characteristic } & \multirow[b]{3}{*}{ Ref } & \multicolumn{17}{|c|}{ Tropical Atlantic } & \multicolumn{5}{|c|}{ Arctic Ocean } & \multicolumn{5}{|c|}{ Antarctic Ocean } \\
\hline & & \multicolumn{14}{|c|}{$2^{\circ} \mathrm{C}$ Isolates } & \multicolumn{3}{|c|}{$20^{\circ} \mathrm{C}$ Isolates } & \multirow[b]{2}{*}{18} & \multirow[b]{2}{*}{19} & \multirow[b]{2}{*}{20} & \multirow[b]{2}{*}{21} & \multirow[b]{2}{*}{22} & \multirow[b]{2}{*}{23} & \multirow[b]{2}{*}{24} & \multirow[b]{2}{*}{25} & \multirow[b]{2}{*}{26} & \multirow[b]{2}{*}{27} \\
\hline & & 1 & 2 & 3 & 4 & 5 & 6 & 7 & 8 & 9 & 10 & 11 & 12 & 13 & 14 & 15 & 16 & 17 & & & & & & & & & & \\
\hline Motility & + & + & + & + & + & + & + & + & + & + & + & + & + & + & + & + & + & NT & - & + & - & + & + & + & + & - & - & + \\
\hline Spore formation & + & $?$ & $?$ & + & $?$ & $?$ & $?$ & $?$ & + & $?$ & - & + & - & + & $?$ & + & + & + & + & + & + & + & - & - & - & - & - & + \\
\hline Oxidase (Kovacs) & $(+)$ & + & $(+)$ & $(+)$ & + & $(-)$ & + & + & $(+)$ & $(+)$ & $(+)$ & + & + & $(+)$ & + & + & $(-)$ & - & + & + & + & + & + & + & + & + & + & + \\
\hline Indophenol oxidase & - & - & - & - & $(+)$ & - & - & - & $(-)$ & $(-)$ & - & $(-)$ & - & - & - & + & $(+)$ & $(-)$ & $(-)$ & $(-)$ & $(-)$ & $(-)$ & $(-)$ & - & $(-)$ & $(-)$ & $(-)$ & \\
\hline Catalase & + & + & + & + & + & + & + & + & + & + & + & + & + & + & + & + & + & + & + & $(+)$ & $(+)$ & $(-)$ & $(-)$ & + & + & + & + & + \\
\hline$\beta$-Galactosidase (ONPG method) & - & - & - & - & - & - & - & - & - & - & - & - & - & - & - & NT & NT & NT & NT & NT & NT & NT & NT & - & + & + & $(+)$ & + \\
\hline$\beta$-Glucosidase & NT & $(+)$ & + & - & - & $(+)$ & + & + & $(+)$ & + & + & + & + & + & + & NT & NT & NT & NT & NT & NT & NT & NT & NT & NT & NT & NT & NT \\
\hline DNase & NT & $(-)$ & $(+)$ & + & - & + & + & $(-)$ & + & + & $(+)$ & + & + & + & + & + & + & + & - & - & - & $(+)$ & - & - & - & - & - & - \\
\hline Lecithinase & NT & - & - & - & - & - & - & - & - & - & - & - & - & - & - & $(+)$ & - & - & NT & NT & NT & NT & NT & NT & NT & NT & NT & NT \\
\hline Urease & - & - & - & - & - & - & - & - & - & - & - & - & - & - & - & $(-)$ & $(+)$ & - & $(-)$ & - & - & - & $(+)$ & - & - & - & - & - \\
\hline Aesculin hydrolysis & + & - & - & - & - & - & + & $(+)$ & - & - & - & - & - & $(-)$ & $(-)$ & $(+)$ & + & + & + & + & + & + & - & + & + & + & + & + \\
\hline Nitrate reduction to nitrite & - & $(+)$ & - & - & - & - & - & - & - & - & - & - & - & - & + & + & + & + & - & - & - & - & - & + & - & - & - & - \\
\hline Gelatin hydrolysis & + & + & - & + & - & + & $(-)$ & $(-)$ & + & $(-)$ & - & + & - & + & $(-)$ & + & + & + & + & + & + & + & + & + & + & - & + & + \\
\hline Casein hydrolysis & + & - & - & - & - & - & - & - & - & - & - & - & - & - & - & - & - & - & NT & NT & NT & NT & NT & NT & NT & NT & NT & $\mathrm{NT}$ \\
\hline $\mathrm{H}_{2} \mathrm{~S}$ production from cysteine & + & + & $(+)$ & - & + & + & + & + & + & + & + & - & + & + & + & + & - & + & $(+)$ & $(+)$ & $(-)$ & $(-)$ & - & $(+)$ & $(-)$ & $(+)$ & $(+)($ & $(+)$ \\
\hline \multicolumn{29}{|l|}{ Susceptibility to: } \\
\hline Pteridine $0 / 129,10 \mu \mathrm{g}$ & + & + & + & + & + & - & - & + & + & - & + & - & + & + & + & $(+)$ & - & + & + & + & + & + & + & + & + & - & + & + \\
\hline \multicolumn{29}{|l|}{ Acid from (Minitek system): } \\
\hline Glucose & + & $(-)$ & - & - & - & - & - & - & - & - & - & - & - & - & + & - & - & - & + & + & + & + & + & + & + & + & + & + \\
\hline Glycerol & + & - & - & - & - & - & - & - & - & - & - & - & - & - & $(-)$ & + & - & - & $(+)$ & + & $(+)$ & $(-)$ & $(-)$ & + & $(+)$ & $(+)$ & $(+)$ & + \\
\hline Maltose & + & - & - & - & - & - & - & - & - & - & - & - & - & - & - & $(+)$ & + & - & - & - & - & - & -1 & $(+)$ & - & - & - & - \\
\hline Mannose & + & $(-)$ & $(-)$ & - & - & $(-)$ & - & - & - & - & - & - & - & - & - & $(+)$ & - & $(+)$ & + & + & + & + & + & + & + & + & + & + \\
\hline Trehalose & + & - & - & - & - & - & - & - & - & - & - & - & - & - & - & - & + & $(+)$ & - & - & - & - & - & - & - & - & - & - \\
\hline Xylose & + & - & - & - & - & - & - & - & - & - & - & - & - & - & - & - & + & - & - & - & - & - & - & - & - & - & - & - \\
\hline
\end{tabular}

oxidase, $\beta$-galactosidase, aesculin, gelatin and mannose test results.

\section{Presence/absence of DAP}

One-dimensional TLC of whole-cell lysates revealed the absence of DAP from the cell walls of the representative strain A02819 (=DSM 11894). Previous analysis of the type strain, $B$. marinus DSM $1297^{\mathrm{T}}$, had shown that the peptide side chains of the peptidoglycan are linked directly through L-lysine, which carries a glycine bound to the carboxyl group (N. Weiß, personal communication).

\section{DNA base composition and DNA-DNA homology}

The DNA base composition was determined for 16 strains and was in the range of 39.6 to $41.6 \mathrm{~mol} \%$ $\mathrm{G}+\mathrm{C}$. No differences were found between the strains of the three sampling sites.

DNA-DNA homologies between strains from all three geographical regions are shown in Table 4. Most homology values were greater than $70 \%$ and showed clearly that the strains from the tropical deep sea and the Arctic and Antarctic oceans belonged to a single species. The high $75 \%$ DNA-DNA homology value of strain A02819 with the type strain of B. marinus, strain
DSM $1297^{\mathrm{T}}$, verified the new isolates as members of this species.

Furthermore, high DNA-DNA homology values between the spore-forming isolates and the three nonspore-forming strains A02767, A02800 and GU4233 confirmed that the non-spore-formers were bacilli that had lost the ability to form endospores.

\section{S rDNA sequence determination}

Eight strains (A02767, A02819, A03029, A03051, AR3393, AR3396, AR3398, GU4234) were selected for partial 16S rDNA gene sequence analysis, including strains from all three expeditions. All strains clustered within Bacillus rRNA group 2 and were found to be closest to B. marinus DSM $1297^{\mathrm{T}}$. The $16 \mathrm{~S}$ rDNA gene sequence similarity values to this strain were in the range of 98.7 to $100.0 \%$. The closest phylogenetic neighbour is $B$. insolitus, with a similarity value of $97 \cdot 1 \%$.

Phylogenetic dendrograms constructed by using the treeing algorithm of De Soete (1983) are not shown here, but are available on request.

Strain A02819 was chosen for complete 16S rDNA gene sequence analysis because of its lowest 16S rDNA gene sequence similarity compared with the sequence 
Table 4. DNA-DNA homology values between pairs of $B$. marinus strains

Values are percentage DNA homology. The type strain of B. marinus, DSM $1297^{\mathrm{T}}$, is identified as Ref. -, Not determined.

\begin{tabular}{|c|c|c|c|c|c|c|c|c|c|c|}
\hline \multirow[t]{2}{*}{ Strain } & \multirow[b]{2}{*}{ Ref } & \multicolumn{5}{|c|}{ Tropical Atlantic } & \multicolumn{2}{|c|}{ Arctic } & \multicolumn{2}{|c|}{ Antarctic } \\
\hline & & 1 & 2 & 3 & 4 & 5 & 6 & 7 & 8 & 9 \\
\hline 1. A02767 & - & 101 & & & & & & & & \\
\hline 2. A02800 & - & 65 & 99 & & & & & & & \\
\hline 3. A02819 & 75 & 67 & 71 & 101 & & & & & & \\
\hline 4. A03029 & - & 69 & 67 & 80 & 101 & & & & & \\
\hline 5. A03051 & - & - & 68 & 74 & 79 & 100 & & & & \\
\hline 6. AR3396 & - & - & - & 81 & 77 & 78 & 100 & & & \\
\hline 7. AR3398 & - & 70 & 67 & 78 & 70 & 75 & 81 & 100 & & \\
\hline 8. GU4233 & - & - & 69 & 82 & 77 & 76 & 83 & 77 & 101 & \\
\hline 9. GU4234 & - & 69 & 70 & 84 & 72 & 75 & 82 & 82 & 83 & 102 \\
\hline
\end{tabular}

of $B$. marinus. On this basis, the similarity value rose to $99 \cdot 4 \%$.

\section{DISCUSSION}

\section{Characteristics and taxonomy of the strains}

On the basis of phenotypic characteristics (Table 3), the absence of DAP, DNA base composition, DNADNA homology (Table 4) and partial and complete $16 \mathrm{~S}$ rDNA gene sequence analysis, the new isolates were assigned to the obligately marine species $B$. marinus.

At the time of the first isolations of B. marinus strains from the Iberian deep sea, tests for utilization of organic compounds as sole sources of carbon and energy were not generally applied. As a consequence, the original descriptions of the species (Rüger \& Richter, 1979; Rüger, 1983) must be regarded as incomplete compared with the current standard. Therefore, combining the taxonomic characteristics of the 18 B. marinus strains already described (Rüger \& Richter, 1979; Rüger, 1983) and the new isolates, an emended description of the species is presented below.

\section{Distribution and origin of $B$. marinus}

The formation of endospores as a survival strategy in terrestrial habitats is an important taxonomic characteristic of the genus Bacillus. However, the ability to form endospores may not be necessary in environments with long periods of uniform environmental conditions, like the deep sea. This may explain why endospores could be detected in only a few of the new $B$. marinus isolates.

Strains of B. marinus have been isolated from sediments of the Iberian deep sea, the tropical Atlantic and the Arctic and Antarctic Oceans. It is not likely that a bacterial species could evolve simultaneously in such distant places. Taking into consideration the known deep-water circulation in the polar and tropical sectors of the Atlantic Ocean (Mantyla \& Reid, 1983; Hollister $\&$ McCave, 1984), it is assumed that the origin of $B$. marinus was in the Antarctic and that the species spread from there to the north.

\section{Emended description of Bacillus marinus (Rüger and Richter) Rüger 1983, emend. Rüger, Fritze and Spröer}

Bacillus marinus (ma'rin.us. L. n. marinus marine).

Gram-positive rods, $0 \cdot 8-1 \cdot 1 \mu \mathrm{m}$ in diameter and $2 \cdot 0$ $7 \cdot 0 \mu \mathrm{m}$ in length. Filaments present. Occurring singly, in pairs and short chains. Motile strains are peritrichously flagellated or the peritrichous flagellation is degenerate. Endospores are round or slightly ellipsoidal and are located terminally to subterminally. The sporangia are not or are only slightly swollen. Strains without the ability to form endospores have been isolated. Colonies on seawater agar are round with entire margin, flat to raised, colourless, mostly translucent; diameter 1-2 $\mathrm{mm}$ after 2 weeks incubation (the extremely psychrophilic strains require longer incubation times of up to 4 weeks at $4{ }^{\circ} \mathrm{C}$ ). Strains require seawater media for growth; the optimum $\mathrm{NaCl}$ concentration for growth is $200-400 \mathrm{mM}$, i.e. $1 \cdot 2-2 \cdot 4 \%$. Growth occurs at $1-4{ }^{\circ} \mathrm{C}$; strains are psychrophilic or psychrotolerant. The highest maximum growth temperature found was $30^{\circ} \mathrm{C}$ and numerous strains did not grow at temperatures exceeding 4 or $8{ }^{\circ} \mathrm{C}$.

The following characteristics are positive for all strains tested: catalase, aerobic acid production from glucose in MOF medium, susceptibility of the 27 new strains to $150 \mu \mathrm{g}$ pteridine 0/129 (2,4-diamino-6,7-diisopropyl pteridine phosphate), $10 \mu \mathrm{g}$ chloramphenicol and $50 \mu \mathrm{g}$ furazolidone (the 18 previous isolates have not been tested).

The following characteristics are negative for all strains tested: anaerobic growth, indole, methyl red, VogesProskauer, arginine dihydrolase, lysine decarboxylase, 
Table 5. Differentiation of cold-adapted Bacillus and Paenibacillus species

Data without superscripts were obtained in the present study. The remaining data were obtained from the following references, as indicated by superscripts: 1, Stackebrandt et al. (1987); 2, N. Weiß (personal communication); 3, Fahmy et al. (1985); 4, F. G. Priest (personal communication); 5, Ash et al. (1991); 6, Nakamura (1984); 7, Rüger (1983); 8, Gordon et al. (1973); 9, Claus \& Berkeley (1986); 10, Abd El-Rahman (1988); 11, Larkin \& Stokes (1967); and 12, Rüger \& Richter (1979). Characteristics are scored as: + , positive; - , negative; \pm , variable result; v, varies among strains. Bd, Buoyant density.

\begin{tabular}{|c|c|c|c|c|c|c|}
\hline Property & B. marinus & B. globisporus & B. insolitus & P. macquariensis & B. psychrophilus & B. psychrosaccharolyticus \\
\hline Spore shape & Round-ellipsoid & Round $^{12}$ & Round-cylindrical ${ }^{12}$ & Ellipsoid $^{9}$ & Round $^{12}$ & Ellipsoid $^{12}$ \\
\hline Sporangium shape & Not swollen & Swollen ${ }^{11}$ & Not swollen ${ }^{11}$ & Swollen $^{9}$ & Swollen ${ }^{11}$ & Swollen $^{11}$ \\
\hline Minimum growth temperature $\left({ }^{\circ} \mathrm{C}\right)$ & $<1-4$ & $<0^{11},-2^{10}, 3^{8}$ & $<0^{12},-2^{10}, 3-5^{8}$ & $0^{11},-2^{10}$ & $<0^{11},-2-5^{10}, 3^{8}$ & $0^{11},-2^{10}, 3^{8}$ \\
\hline \multicolumn{7}{|l|}{ Growth at: } \\
\hline $23 / 24^{\circ} \mathrm{C}$ & $\mathrm{v}$ & $+{ }^{11}$ & $+{ }^{11}$ & $+{ }^{10}$ & $+{ }^{11}$ & $+{ }^{11}$ \\
\hline $30^{\circ} \mathrm{C}$ & $\mathrm{v}$ & $-{ }^{11}$ & -11 & $-9,10$ & $+{ }^{11}$ & $+{ }^{11}$ \\
\hline $\mathrm{NaCl}$ required & + & $-{ }^{9}$ & -9 & -9 & -11 & $-{ }^{11}$ \\
\hline \multicolumn{7}{|l|}{ Growth at: } \\
\hline $2 \% \mathrm{NaCl}$ & + & $+{ }^{11}$ & $\pm^{11}$ & $++^{9}$ & $+{ }^{11}$ & $+{ }^{11}$ \\
\hline $3 \% \mathrm{NaCl}$ & + & $-{ }^{6},+{ }^{10}$ & -10 & -9 & $+^{6,10}$ & $+{ }^{10}$ \\
\hline $5 \% \mathrm{NaCl}$ & $\mathrm{v}$ & $-9,10$ & $-9,10$ & $-9,10$ & $v^{6,10}$ & -10 \\
\hline Anaerobic growth & - & $-{ }^{10},+{ }^{11}$ & $-{ }^{10,11}$ & $+^{9,10}$ & $+^{6,11},-^{8}$ & $+^{8,11}, \pm^{10}$ \\
\hline Starch hydrolysis & - & $-6,11$ & -11 & $++^{9,10}$ & $-6,11$ & $+{ }^{11}$ \\
\hline Urea digestion & - & $++^{11}$ & $-{ }^{11}$ & $-9,10$ & $+^{6,11}$ & $-{ }^{11}$ \\
\hline $\mathrm{NO}_{3}$ reduction to $\mathrm{NO}_{2}$ & $\mathrm{v}$ & $-6,11$ & $-{ }^{11}$ & $-9,10$ & $+{ }^{6,11}$ & $+{ }^{11}$ \\
\hline Cell wall & $\begin{array}{l}\text { L-Lys direct (Gly) at } \\
\text { carboxyl group }{ }^{2}\end{array}$ & L-Lys-D-Glu ${ }^{1}$ & L-Orn-D-Glu ${ }^{1}$ & $\mathrm{DAP}^{10}$ & L-Lys-D-Glu ${ }^{1}$ & $\mathrm{DAP}^{10}$ \\
\hline DNA $\mathrm{G}+\mathrm{C}$ content $(\mathrm{mol} \%)$ & $\begin{array}{c}39 \cdot 6-41 \cdot 6\left(T_{\mathrm{m}}\right), 36 \cdot 9-39 \cdot 5 \\
\left(T_{\mathrm{m}}\right)^{12}, 37 \cdot 6\left(T_{\mathrm{m}}\right)^{3} \\
38 \cdot 0(\mathrm{Bd})^{3}\end{array}$ & $\begin{array}{c}39 \cdot 8\left(T_{\mathrm{m}}\right)^{3}, 39 \cdot 7(\mathrm{Bd})^{3}, \\
40 \cdot 6\left(T_{\mathrm{m}}\right)^{7}\end{array}$ & $35 \cdot 9\left(T_{\mathrm{m}}\right)^{3}, 36 \cdot 1(\mathrm{Bd})^{3}$ & $\begin{array}{c}39 \cdot 3\left(T_{\mathrm{m}}\right)^{3}, 41 \cdot 6 \\
(\mathrm{Bd})^{3}\end{array}$ & $\begin{array}{l}39 \cdot 7\left(T_{\mathrm{m}}\right)^{3,7}, 40 \cdot 5 \\
(\mathrm{Bd})^{3}, 44 \cdot 1(\mathrm{Bd})^{6}\end{array}$ & $43-44^{4}$ \\
\hline rRNA Group & 2 & $2^{5}$ & $2^{5}$ & $3^{5}$ & $2^{5}$ & $1^{5}$ \\
\hline
\end{tabular}

ornithine decarboxylase, nitrate reduction to gas and digestion of starch and chitin.

No aerobic acid production (Minitek system) from arabinose, cellobiose, lactose, mannitol, raffinose, rhamnose, salicin, sorbitol or sucrose. The following compounds are not utilized. Carbohydrates: L-arabinose, cellobiose, D-galactose, gluconate, D-glucose, maltose, D-mannose, D-ribose, salicin, sucrose, trehalose and D-xylose. Carboxylic acids: acetate, adipate, citrate, DL-3-hydroxybutyrate, fumarate, lactate, propionate, pyruvate and succinate. Alcohols: glycerol, mannitol and sorbitol. Amino acids: Lalanine, L-arginine, L-aspartate, L-glutamate, Lhistidine, L-lysine and L-ornithine. Others: putrescine, $p$-hydroxybenzoate and quinate.

The following characteristics give strain-dependent results: oxidase (Kovacs), indophenol oxidase, $\beta$ galactosidase, $\beta$-glucosidase, DNase, lecithinase, urease, aesculin hydrolysis, $\mathrm{NO}_{3}$ reduction to $\mathrm{NO}_{2}$, gelatin hydrolysis, casein hydrolysis, $\mathrm{H}_{2} \mathrm{~S}$ from cysteine, susceptibility to $2 \mathrm{U}$ penicillin $\mathrm{G}, 10 \mu \mathrm{g}$ pteridine $0 / 129$ and $10 \mu \mathrm{g}$ tetracycline. Acid from the following carbohydrates, determined with the Minitek system: glucose, glycerol, maltose, mannose, trehalose and xylose.

The $\mathrm{G}+\mathrm{C}$ content of DNA $\left(T_{\mathrm{m}}\right)$, based on 16 of the new isolates, is $39 \cdot 6-41 \cdot 6 \mathrm{~mol} \%$. The $\mathrm{G}+\mathrm{C}$ contents of four of the previous isolates from the Iberian deep sea were in a lower range of between 36.9 and $39.5 \mathrm{~mol} \%$. Results of DNA G $+\mathrm{C}$ content analyses of the type strain: $39 \cdot 3$ [Rüger \& Richter, $1979\left(T_{\mathrm{m}}\right)$ ],
$37 \cdot 6$ [Fahmy et al., $\left.1985\left(T_{\mathrm{m}}\right)\right]$ and $38.0 \mathrm{~mol} \%$ [Fahmy et al., 1985 (buoyant density)]. The EMBL accession number of the 16S rDNA gene sequence of B. marinus DSM $1297^{\mathrm{T}}$ is AJ 237708 .

The type strain is DSM $1297^{\mathrm{T}}\left(=\mathrm{ATCC} 29841^{\mathrm{T}}\right)$. Source: isolated from sediments of the Iberian deep sea, the tropical eastern Atlantic and the Arctic and Antarctic seas. Habitat: Marine sediments. Characteristics useful for differentiation of $B$. marinus from other psychrophilic or psychrotolerant Bacillus and Paenibacillus species are listed in Table 5.

\section{ACKNOWLEDGEMENTS}

We thank Christa Ehrich and Angelika Meyer (AWI) for their excellent technical assistance in phenotypic characterization of the strains and in preparing DNA for DNA base analyses and hybridizations and Ina Kramer and Ulrike Mendrock (DSMZ) for their help in 16S rDNA sequencing and DNA-DNA hybridizations with the type strain of $B$. marinus.

This paper is publication no. 1746 of the Alfred-WegenerInstitut für Polar- und Meeresforschung.

\section{REFERENCES}

Abd El-Rahman, H. A. (1988). Taxonomische Untersuchungen an psychrotrophen Bacillus-Stämmen. $\mathrm{PhD}$ thesis, Georg-AugustUniversität Göttingen, Germany.

Ash, C., Farrow, J. A. E., Wallbanks, S. \& Collins, M. D. (1991). Phylogenetic heterogeneity of the genus Bacillus revealed by comparative analysis of small-subunit ribosomal RNA sequences. Lett Appl Microbiol 13, 202-206.

Baross, J. A. \& Morita, R. Y. (1978). Microbial life at low 
temperatures: ecological aspects. In Microbial Life in Extreme Environments, pp. 9-71. Edited by D. J. Kushner. London \& New York: Academic Press.

Boeyé, A. \& Aerts, M. (1976). Numerical taxonomy of Bacillus isolates from North Sea sediments. Int J Syst Bacteriol 26, 427-441.

Bonde, G. J. (1981). Bacillus from marine habitats: allocation to phena established by numerical techniques. In The Aerobic Endospore-forming Bacteria: Classification and Identification, pp. 181-215. Edited by R. C. W. Berkeley \& M. Goodfellow. London \& New York: Academic Press.

Brisou, J. \& Denis, F. (1969). Deux écotypes halophiles stricts de bactéries à Gram positif. C R Soc Biol 163, 2665-2668.

Brisou, J., de Barjac, H. \& Moreau, R. (1978). Sur quelques Bacillus isolés en mer Méditerranée. Rev Cytol Biol Vég Bot 1, 405-412.

Cashion, P., Holder-Franklin, M. A., McCully, J. \& Franklin, M. (1977). A rapid method for the base ratio determination of bacterial DNA. Anal Biochem 81, 461-466.

Claus, D. \& Berkeley, R. C. W. (1986). Genus Bacillus Cohn 1872 , $174^{\mathrm{AL}}$. In Bergey's Manual of Systematic Bacteriology, vol. 2, pp. 1105-1139. Edited by P. H. A. Sneath, N. S. Mair, M. E. Sharpe \& J. G. Holt. Baltimore: Williams \& Wilkins.

De Ley, J. (1970). Reexamination of the association between melting point, buoyant density, and chemical base composition of deoxyribonucleic acid. J Bacteriol 101, 738-754.

De Ley, J., Cattoir, H. \& Reynaerts, A. (1970). The quantitative measurement of DNA hybridization from renaturation rates. Eur J Biochem 12, 133-142.

Denis, F.-A., Geslin, M. \& Brisou, J. (1975). Identification et étude des activités métaboliques de 290 souches de Bacillus, isolées à partir de divers milieux aquatiques. J Fr Hydrol 18, 27-32.

De Soete, G. (1983). A least squares algorithm for fitting additive trees to proximity data. Psychometrika 48, 621-626.

Fahmy, F. A. (1978). Untersuchungen zur Taxonomie farbstoffbildender Bacillus-Stämme aus Salzmarsch- und Wattböden. PhD thesis, Georg-August-Universität Göttingen, Germany.

Fahmy, F., Flossdorf, J. \& Claus, D. (1985). The DNA base composition of the type strains of the genus Bacillus. Syst Appl Microbiol 6, 60-65.

Fritze, D., Flossdorf, J. \& Claus, D. (1990). Taxonomy of alkaliphilic Bacillus strains. Int J Syst Bacteriol 40, 92-97.

Gillis, M., De Ley, J. \& De Cleene, M. (1970). The determination of molecular weight of bacterial genome DNA from renaturation rates. Eur J Biochem 12, 143-153.

Gordon, R. E., Haynes, W. C. \& Pang, C. H.-N. (1973). The Genus Bacillus, Agriculture Handbook no. 427. Washington, DC: US Department of Agriculture.

Hollister, C. D. \& McCave, I. N. (1984). Sedimentation under deep-sea storms. Nature 309, 220-225.

Jahnke, K.-D. (1992). Basic computer program for evaluation of spectroscopic DNA renaturation data from Gilford System 2600 spectrometer on a PC/XT/AT type personal computer. J Microbiol Methods 15, 61-73.

Jukes, T. H. \& Cantor, C. R. (1969). Evolution of protein molecules. In Mammalian Protein Metabolism, pp. 21-132. Edited by H. N. Munro. New York: Academic Press.

Kandler, O. \& Weiss, N. (1986). Genus Lactobacillus Beijerinck 1901, 212 $\mathrm{AL}$. In Bergey's Manual of Systematic Bacteriology, vol. 2, pp. 1209-1234. Edited by P. H. A. Sneath, N. S. Mair, M. E. Sharpe \& J. G. Holt. Baltimore: Williams \& Wilkins.
Laine, J. J. (1970). Studies on psychrophilic bacilli of food origin. Ann Acad Sci Fenn Ser A IV Biol 169, 1-36.

Larkin, J. M. \& Stokes, J. L. (1966). Isolation of psychrophilic species of Bacillus. J Bacteriol 91, 1667-1671.

Larkin, J. M. \& Stokes, J. L. (1967). Taxonomy of psychrophilic strains of Bacillus. J Bacteriol 94, 889-895.

Leifson, E. (1963). Determination of carbohydrate metabolism of marine bacteria. J Bacteriol 85, 1183-1184.

Maidak, B. L., Olsen, G. J., Larsen, N., Overbeek, R., McCaughey, M. J. \& Woese, C. R. (1996). The Ribosomal Database Project (RDP). Nucleic Acids Res 24, 82-85.

Mantyla, A. W. \& Reid, J. L. (1983). Abyssal characteristics of the world ocean waters. Deep-Sea Res 30, 805-833.

Marmur, J. \& Doty, P. (1962). Determination of the base composition of deoxyribonucleic acid from its thermal denaturation temperature. J Mol Biol 5, 109-118.

Marshall, B. J. \& Ohye, D. F. (1966). Bacillus macquariensis n.sp., a psychrotrophic bacterium from sub-Antarctic soil. J Gen Microbiol 44, 41-46.

Morita, R. Y. (1975). Psychrophilic bacteria. Bacteriol Rev 39, 144-167.

Nakamura, L. K. (1984). Bacillus psychrophilus sp. nov., nom. rev. Int J Syst Bacteriol 34, 121-123.

Nedwell, D. B. \& Rutter, M. (1994). Influence of temperature on growth rate and competition between two psychrotolerant Antarctic bacteria: low temperature diminishes affinity for substrate uptake. Appl Environ Microbiol 60, 1984-1992.

Rainey, F. A., Ward-Rainey, N., Kroppenstedt, R. M. \& Stackebrandt, E. (1996). The genus Nocardiopsis represents a phylogenetically coherent taxon and a distinct actinomycete lineage: proposal of Nocardiopsaceae fam. nov. Int $J$ Syst Bacteriol 46, 1088-1092.

Rüger, H.-J. (1975). Bakteriensporen in marinen Sedimenten (Nordatlantik, Skagerrak, Biskaya und Auftriebsgebiet vor Nordwestafrika) - quantitative Untersuchungen. Veröff Inst Meeresforsch Bremerhaven 15, 227-236.

Rüger, H.-J. (1981). Comparison of the API and Minitek identification systems with conventional methods for differentiating marine bacteria. Veröff Inst Meeresforsch Bremerhaven 19, 21-34.

Rüger, H.-J. (1983). Differentiation of Bacillus globisporus, Bacillus marinus comb. nov., Bacillus aminovorans, and Bacillus insolitus. Int J Syst Bacteriol 33, 157-161.

Rüger, H.-J. (1988). Substrate-dependent cold adaptations in some deep-sea sediment bacteria. Syst Appl Microbiol 11, 90-93.

Rüger, H.-J. (1989). Benthic studies of the northwest African upwelling region: psychrophilic and psychrotrophic bacterial communities from areas with different upwelling intensities. Mar Ecol Prog Ser 57, 45-52.

Rüger, H.-J. \& Hentzschel, G. (1980). Mineral salt requirements of Bacillus globisporus subsp. marinus strains. Arch Microbiol 126, 83-86.

Rüger, H.-J. \& Höfle, M. G. (1992). Marine star-shaped-aggregateforming bacteria: Agrobacterium atlanticum sp. nov.; Agrobacterium meteori sp. nov.; Agrobacterium ferrugineum sp. nov., nom. rev.; Agrobacterium gelatinovorum sp. nov., nom. rev.; and Agrobacterium stellulatum sp. nov., nom. rev. Int $J$ Syst Bacteriol 42, 133-143.

Rüger, H.-J. \& Koploy, J. A. C. (1980). DNA base compositions of halophilic and nonhalophilic Bacillus firmus strains of marine origin. Microb Ecol 6, 141-146. 
Rüger, H.-J. \& Richter, G. (1979). Bacillus globisporus subsp. marinus subsp. nov. Int J Syst Bacteriol 29, 196-203.

Rüger, H.-J. \& Tan, T. L. (1992). Community structures of cold and low-nutrient adapted heterotrophic sediment bacteria from the deep eastern tropical Atlantic. Mar Ecol Prog Ser 84, 83-93.

Russell, N. J. (1993). Biochemical differences between psychrophilic and psychrotolerant microorganisms. In Trends in $\mathrm{Mi}$ crobial Ecology, Proceedings of the Sixth International Symposium on Microbial Ecology, Barcelona, 6-11 September 1992, pp. 29-32. Edited by R. Guerrero \& C. Pedrós-Alió. Barcelona: Spanish Society for Microbiology.

Sarnthein, M., Kögler, F. \& Werner, F. (1983). RV Meteor. Cruise no. 65: Equatorial East Atlantic - GEOTROPEX '83, JuneAugust 1983. Geologisch-Paläontologisches Institut der Universität Kiel, Berichte - Reports, no. 2. Kiel: GeologischPaläontologisches Institut der Universität Kiel.

Stackebrandt, E., Ludwig, W., Weizenegger, M., Dorn, S., McGill, T. J., Fox, G. E., Woese, C. R., Schubert, W. \& Schleifer, K.-H. (1987). Comparative 16S rRNA oligonucleotide analyses and murein types of round-spore-forming bacilli and non-sporeforming relatives. J Gen Microbiol 133, 2523-2529.

Tan, T. L. \& Rüger, H.-J. (1991). Biomass and nutritional requirements of psychrotrophic bacterial communities in Fram Strait and Western Greenland Sea. Kiel Meeresforsch Sonderh 8, 219-224.

Tan, T. L., Joiris, C. R., Glansdorff, N. \& Rüger, H.-J. (1999). Dominance of oligotrophic bacteria in surface waters above Gunnerus and Astrid Ridge, Antarctic Ocean. Arch Hydrobiol Spec Issues Adv Limnol 54, 237-253.

Zain-ul-Abedin, Lopez, J. M. \& Freese, E. (1983). Induction of bacterial differentiation by adenine- and adenosine-analogs and inhibitors of nucleic acid synthesis. Nucleosides $\&$ Nucleotides $\mathbf{2}$, 257-274.

ZoBell, C. E. (1946). Marine Microbiology. Waltham, MA: Chronica Botanica Company.

ZoBell, C. E. \& Upham, H. C. (1944). A list of marine bacteria including descriptions of sixty new species. Bull Scripps Inst Oceanogr Univ Calif 5, 239-292. 